\title{
INOVASI KEBIJAKAN PUBLIK (TINJAUAN KONSEPTUAL DAN EMPIRIS)
}

\author{
Ahmad Sururi \\ Program Studi Administrasi Negara Fakultas Ilmu Sosial dan Politik \\ Universitas Serang Raya \\ Jalan Raya Cilegon-Serang Km. 5, Drangong, Serang, Banten \\ Email : ahmadbroer@gmail.com
}

\begin{abstract}
ABSTRAK
Tujuan dari penelitian ini adalah menganalisis inovasi kebijakan publik dalam perspektif konseptual dan empiris disertai dengan berbagai contoh penerapan kebijakan publik yang berbasis inovatif dari berbagai daerah. Inovasi kebijakan publik sebagai sebuah keniscayaan secara prinsip dan substantif akan memberikan penguatan dalam merespon dan menyelesaikan problematika kebijakan publik yang berlangsung di tengah masyarakat. Metode yang digunakan adalah pendekatan kualitatif. Teknik yang dilakukan oleh peneliti adalah survei literatur akademis di bidang keilmuan kebijakan publik guna memperoleh konsep-konsep yang relevan dengan kajian inovasi kebijakan publik. Sedangkan pengumpulan data dilakukan melalui penelusuran berbagai sumber baik dari dokumen pemerintah maupun pemberitaan media massa cetak dan elektronik sebagai data sekunder yang kemudian diolah dan dideskripsikan dalam bentuk narasi sesuai dengan kebutuhan data. Kemudian dilakukan analisis data berdasarkan teori dan konsep kebijakan publik serta selanjutnya dilakukan proses intreprtasi data. Hasil yang ingin dicapai dalam penelitian ini adalah adanya upaya-upaya inovasi kebijakan publik yang berdimensi kebaruan dan kemanfaatan sehingga diharapkan dapat memberikan dampak pada upaya yang lebih kongkrit dan membangun partisipasi masyarakat secara berkesinambungan. Inovasi diterapkan bukan hanya pada tahap evaluasi kebijakan publik akan tetapi diterapkan sejak awal perencanaan kebijakan publik, implementasi dan evaluasi kebijakan publik.
\end{abstract}

Keyword: Inovasi Kebijakan Publik, Kebijakan Publik.

\section{A. Pendahuluan}

$$
\begin{array}{rrr}
\text { Paradigma } & \text { kebijakan publik yang } \\
\text { responsif dan memberikan ruang bagi }
\end{array}
$$

berkembangnya masyarakat secara mandiri dalam proses formulasi, implementasi maupun evaluasi kebijakan akan memberikan dampak pada peningkatan kesejahteraan masyarakat secara berkelanjutan. Dengan demikian dibutuhkan interaksi, proses dan aktivitas antara masyarakat dan pemerintah secara simbiosis mutalisme sehingga diharapkan akan mampu menjawab dinamika, tuntutan dan kepentingan publik. Kebijakan publik di sisi lain adalah produk yang memperjuangkan kepentingan publik yang filosofinya adalah mensyaratkan pelibatan publik sejak awal hingga akhir ${ }^{1}$. Publik sebagai aktor utama kebijakan adalah sub stakeholder yang secara persis mengetahui apa dan bagaimana kebutuhan dan kepentingannya. Hal tersebut mensyaratkan pergeseran peran pemerintah bukan lagi sebagai provider akan tetapi sebagai fasilitator dan regulator suatu kebijakan. Peran pemerintah tersebut akan berjalan efektif apabila output kebijakan publik mampu beradaptasi dan berinovasi terhadap berbagai perubahan guna

\footnotetext{
1 Riant Nugroho, 2014, Public Policy, Teori, Manajemen, Dinamika, Analisis, Konvergensi dan Kimia Kebijakan (Ikapi Jakarta) Halaman 43
} 
mendorong sinergitas antara berbagai kepentingan.

Kata inovasi sudah sering kita dengar dalam berbagai aspek kehidupan dan merupakan salah satu faktor yang berperan penting dalam menghadapi dan mengatasi berbagai permasalahan baik menyangkut individu, masyarakat, organisasi dan negara. Dalam konteks relasi negara dan publik, negara berperan sebagai aktor fasilitator dan regulator kebijakan publik sedangkan inovasi sebagai keyword strategis manakala output dan outcome dalam kebijakan sudah tidak dapat memenuhi tuntutan dan dinamika perkembangan masyarakat yang semakin global. Pada titik ini, maka inovasi diperlukan untuk memberikan penguatan pada sektor-sektor kebijakan publik dengan spektrumnya yang lebih luas. Perubahan strategis kebijakan publik sebagai bentuk nyata dari inovasi hendaknya dimaknai sebagai salah satu preferensi agar kebijakan publik mempunyai nilai kebaruan dan kebermanfaatan bagi masyarakat secara luas.

Harapan yang besar terhadap kebijakan publik yang berkualitas merupakan salah satu faktor pendorong lahirnya kebijakan publik yang berdimensi kepublikan dan tidak hanya terbatas pada persoalan isu-isu dan agenda kebijakan. Dengan demikian kebijakan publik tidak berada dalam area eksklusif dan melakukan pembatasan terhadap pertanyaan-pertanyaan kritis publik, akan tetapi kebijakan publik dapat bergerak secara simultan dan berada dalam garis kontinum beriringan dengan publik. Dalam hal ini kebijakan publik berfungsi sama dengan otak pada tubuh manusia, karena melalui instrumen ini segala aktivitas kehidupan bernegara dan bermasyarakat mulai dilakukan oleh birokrasi plus pihak swasta dan masyarakat ${ }^{2}$. Oleh sebab itu dalam konteks memahami kebijakan publik yang mampu memberikan impact dan benefit, maka diperlukan inovasi kebijakan publik sebagai bentuk dorongan yang lebih luas yaitu berupa ekspansi dan modifikasi kebijakan yang bersifat kebaruan dan kebermanfaatan baik dari aspek formulasi, proses maupun evaluasi kebijakan.

Perhatian terhadap semakin pentingnya inovasi kebijakan dikemukakan oleh Menteri PPN/Kepala Bappenas Bambang PS Brodjonegoro dengan mengajak dan meminta kepada kepala daerah untuk mengedepankan beragam inovasi kebijakan dalam masa kepemimpinannya. "Selain kerapihan administrasi, inovasi kebijakan dan program juga tidak kalah pentingnya" (www. id.beritasatu.com, 23 Februari 2017). Dalam konteks ini kapasitas inovator menjadi semakin penting dalam melakukan sebuah inovasi karena akan memberikan banyak manfaat. Inovasi bertujuan untuk merevitalisasi administrasi publik, membuatnya lebih pro aktif, efisien, akuntabel dan lebih berorientasi pada pelayanan ${ }^{3}$. Oleh sebab itu kemampuan pejabat publik dalam melakukan inovasi akan menjadi peran yang menentukan dan diharuskan memiliki prasyarat keterampilan dan pengetahuan memadai. Untuk menginisasi, menjalankan, dan mengelola inovasi administrasi negara, maka para inovator harus menyadari bahwa pemahaman dan penguasaan

\footnotetext{
${ }^{2}$ Deddy Mulyadi, 2015, Studi Kebijakan Publik dan Pelayanan Publik (Bandung Alfabeta), hal 1

${ }^{3}$ United Nations, $2006: 2$ dalam Innovation Discusion Paper, Tri Widodo Wahyu Utomo, 2016:8
} 
yang mumpuni akan ragam keterampilan dan pengetahuan menjadi prasyarat ${ }^{4}$. Maka dengan prasyarat tersebut inovasi kebijakan akan memberikan dampak yang bersifat strategis.

Sejalan dengan diberlakukannya otonomi daerah yang memberikan kewenangan bagi pemerintah daerah untuk menyusun kebijakan, maka peran pejabat publik di daerah dalam melakukan inovasi kebijakan publik akan semakin meningkat dan memberikan dampak yang positif bagi kualitas kebijakan atau peraturan yang akan disusun dan telah dihasilkan. Kualitas peraturan daerah menjadi indikator penting kinerja tata pemerintahan di daerah $^{5}$. Akan tetapi faktanya, hampir semua pembuat kebijakan masih dominan mempertimbangkan kepentingan jangka pendek dan parsial serta belum mengedepankan budaya inovasi sehingga mengakibatkan terjadinya stagnasi kebijakan publik dan kinerja tata pemerintahan belum berjalan secara optimal.

Persoalan rendahnya kemampuan berinovasi (ability to innovate) dan kemauan berinovasi (willingnes to inovate) menjadi salah satu tantangan bagi kalangan pejabat publik di instansi pemerintah baik di daerah maupun pusat. Di sisi lain kebijakan publik sebagai instrumen yang berfungsi menyatukan pemerintah dan masyarakat belum berjalan secara optimal, hal ini

\footnotetext{
4 Pusat Invovasi Tata Pemerintahan Deputi Inovasi Administrasi Negara, 2014, Handbook Administrasi Negara, (Lembaga Administrasi Negara Pusat Intan Dian - LAN), hal 16

${ }^{5}$ Agus Dwijanto et. al, Kinerja Tata Pemerintahan di Indonesia, Yogyakarta: Pusat Studi Kependudukan dan Kebijakan Universitas Gajah Mada (PSKK UGM)- Kemitraan, 2007, hlm. 10
}

disebabkan karena masih terdapat tumpang tindih kebijakan yang dikeluarkan oleh instansi pembuat kebijakan yang berbeda. Contoh dari kegagalan kebijakan pelayanan publik di Indonesia dalam wujud adanya diskonektivitas dari output kegiatan Kementerian dan Lembaga Non-Kementerian, sebagai misal, beberapa waduk yang sudah dibangun oleh pemerintah tidak dapat berfungsi karena tidak ada saluran irigasi, pelabuhan tidak dapat beroperasi secara wajar karena tidak ada jalan yang menghubungkannya dengan kawasan industri ${ }^{6}$. Untuk menghindari terminasi kebijakan tersebut, maka perlu adanya reorientasi kebijakan yang lebih terfokus baik dalam hal proses, metode maupun produk setiap kebijakan publik yang dihasilkan.

Inovasi kebijakan publik sebagai sebuah keniscayaan secara prinsip dan substantif akan memberikan penguatan dalam merespon dan menyelesaikan problematika di tengah masyarakat. Persoalan-persoalan seperti disparitas pembangunan karena kurang tepatnya analisis kebijakan, perilaku koruptif para pejabat publik, ketahanan pangan, persoalan kemiskinan dan pengangguran dan pendidikan yang rendah merupakan beberapa contoh kegagalan kebijakan publik dalam memecahkan permasalahan tersebut. Inovasi menjadi salah satu alternatif terbaik dalam dimensi kebijakan publik di masa kini dan masa yang akan datang. Tulisan ini dimaksudkan untuk mengkaji inovasi kebijakan publik dalam perspektif konseptual dan empiris disertai dengan berbagai contoh penerapan

\footnotetext{
${ }^{6}$ Agus Dwiyanto (2015) dalam Tri Widodo Wahyu Utomo, 2016, Inovasi sebagai keniscayaan baru dalam Ilmu dan Praktek Administrasi Publik di Indonesia, Laskar Inovasi Deputi Inovasi Administrasi Negara
} 
kebijakan publik yang berbasis inovatif dari berbagai daerah.

\section{B. Metode Penelitian}

Metode yang digunakan adalah pendekatan kualitatif. Teknik yang dilakukan oleh peneliti adalah survei literatur akademis di bidang keilmuan kebijakan publik guna memperoleh konsep-konsep yang relevan dengan kajian inovasi kebijakan publik. Sedangkan pengumpulan data dilakukan melalui penelusuran berbagai sumber baik dari dokumen pemerintah maupun pemberitaan media massa cetak dan elektronik sebagai data sekunder yang kemudian diolah dan dideskripsikan dalam bentuk narasi sesuai dengan kebutuhan data. Kemudian dilakukan analisis data berdasarkan teori dan konsep kebijakan publik serta selanjutnya dilakukan proses intreprtasi data.

\section{Hasil Analisis dan Diskusi}

\section{C.1. Stagnasi Inovasi Kebijakan Publik}

Prasyarat mutlak inovasi kebijakan publik adalah terwujudnya gagasan dan ide dari pejabat publik sebagai entry point diimplementasikannya berbagai program-program dan kebijakan. Gagasan dan ide dapat terealisasikan apabila organisasi sektor publik sebagai locus pembuatan kebijakan mampu melakukan adopsi dan adaptasi terhadap perkembangan yang terjadi di luar organisasi. Mekanisme sistem organisasi sektor publik yang melibatkan lingkungan organisasi sebagai input dan proses organisasi menjadi bagian yang tidak dapat terpisahkan dari setiap perumusan kebijakan publik. Persoalannya kemudian masih banyak kebijakan publik yang sudah tidak up to date dan dianggap menghambat investasi pembangunan. Fakta menunjukkan bahwa banyak peraturan di daerah yang dicabut dikarenakan tidak memberikan manfaat bagi kepentingan masyarakat. Menteri Dalam Negeri (Mendagri), Tjahjo Kumolo menegaskan pemerintah secepatnya akan mencabut 3.266 perda yang dinilai menghambat masuknya investasi. Tjahjo menjelaskan, kategori perda bermasalah adalah menghambat investasi, perizinan, dan retribusi yang tidak perlu. Misalnya, orang yang ingin buka usaha harus diminta izin prinsip, izin usaha, izin mendirikan bangunan (IMB). (www.jawaPos.com, 13 Juni 2016).

Terhambatnya kebijakan publik melakukan perubahan disebabkan oleh banyak faktor, diantaranya seperti rendahnya kapasitas pejabat publik, budaya birokrasi yang antipati terhadap perubahan dan struktur birokrasi yang cenderung kaku dan kurang fleksibel. Dalam kasus tertentu, banyak terjadi orientasi kebijakan publik yang berbeda antara pemerintah dan publik terutama dalam proses formulasi kebijakan sehingga menyebabkan ketidakharmonisan pada tataran implementasi. Pemerintah berorientasi kepada bagaimana membelanjakan anggaran supaya terserap dan dapat dipertanggungjawabkan, sehingga kerap kali lalai terhadap program yang bersentuhan langsung dengan kepentingan publik ${ }^{7}$. Kondisi tersebut memaksa publik untuk tetap patuh terhadap kebijakan dari pemerintah yang tidak memberikan dampak dan manfaat kepentingan publik.

\footnotetext{
${ }^{7}$ Dede Mariana, 2010, Otonomi Daerah dan Inovasi Kebijakan Publik, Jurnal Governance Vol. 1 No.1
} 
Salah satu persoalan yang masih menyebabkan terjadinya stagnasi inovasi kebijakan publik adalah masih dominannya peran leader atau pemimpin, ketergantungan bawahan terhadap leader membuat seluruh sistem tidak berjalan seperti yang diharapkan, bawahan cenderung pasif dan kurang melakukan inisiatif dan berpartisipasi dalam memecahkan permasalahan. Kajian akademis tentang inovasi mensyaratkan adanya peran leader sebagai administrator There is no innovation without leadership ${ }^{8}$. Padahal integrasi budaya inovasi dalam kebijakan publik harus berjalan dalam sebuah sistem yang terstruktur dan akomodatif terhadap berbagai kepentingan masyarakat. Hal ini diperlukan karena masih terdapatnya disparitas antara ekspektasi masyarakat dengan kebijakan publik dan menghindari terjadinya stagnasi kebijakan publik, akan tetapi di sisi lain kesadaran inovasi di birokrasi sifatnya masih sporadis, stagnan dan cenderung tidak jelas ${ }^{9}$. Persoalan bahwa inovasi tergantung sepenuhnya kepada leader menjadi tantangan bagi birokrasi untuk menciptakan inovasi kebijakan publik melalui mekanisme sistem birokrasi. Pendapat bahwa inovasi kebijakan publik masih sangat terbatas adalah fakta yang terjadi pada saat ini di birokrasi. Inovasi kebijakan dan kreativitas yang digagas oleh pemimpin adalah penting akan tetapi sebuah sistem pelayanan publik yang baik tidak bergantung pada siapa yang memimpin. Saat masyarakat mengadu atau melapor, secara

\footnotetext{
${ }^{8}$ Morris (2006) dalam Irwan Noor (2016) Jurnal Ilmiah Administrasi Publik Universitas Brawijaya Malang, Determinasi Pelayanan Publik Pemerintahan Daerah : Paradoks di Era Desentralisasi, hal 132

${ }^{9}$ Tri Widodo, 10 November 2016, http://lan.go.id/id
}

sistemik pula bisa segera direspon oleh pemerintah $^{10}$. Oleh sebab itu sebuah inovasi kebijakan tidak hanya tergantung kepada seorang leader akan tetapi pada mekanisme sistem yang bekerja berdasarkan nilai-nilai organisasi publik.

\section{C.2. Inovasi Kebijakan Publik dalam perspektif konseptual}

Inovasi diartikan sebagai suatu ide, produk, informasi teknologi, kelembagaan, perilaku, nilainilai, dan praktek-praktek baru atau objek-objek yang dapat dirasakan sebagai sesuatu yang baru oleh individu atau masyarakat ${ }^{11}$. Aspek sesuatu yang baru tersebut dapat terbentuk melalui sebuah proses modifikasi. Dan kebijakan publik diartikan sebagai suatu program yang diproyeksikan dengan tujuantujuan tertentu, nilai-nilai tertentu dan praktekpraktek tertentu (a projected program of goals, values, and practices $^{12}$ ). Secara konseptual, inovasi kebijakan publik terbagi menjadi a). Policy innovation: new policy direction and initiatives yaitu inovasi kebijakan yang dimaksud adalah adanya inisiatif dan arah kebijakan baru. Ini dapat diartikan bahwa setiap kebijakan publik yang dikeluarkan pada prinsipnya harus dapat memuat sesuatu yang baru. b). Innovation in the policy making process. Pada peranan ini, yang menjadi fokus adalah inovasi yang dapat memengaruhi proses pembuatan atau perumusan kebijakan.

10 Agus Heruanto Hadna, Kepala Pusat Studi Kependudukan dan Kebijakan Universitas Gadjah Mada, 12 November 2016, http://cpps.ugm.ac.id

${ }^{11}$ Rogers(1995) dalam Lydia Wijayanti (2012) Jurnal Pembangunan Wilayah dan Kota, Implementasi Kebijakan Pembangunan berkelanjutan di Kota Surakarta : Relokasi PKL di Taman Monumen Banjarsari ke pasar Klitikan Notoharjo, hal 129

12 Harlod Laswell dan Abraham Kaplan (1970:71) dalam Riant Nugroho, 2014, Public Policy, PT. Elex Media Komputindo Gramedia, Jakarta hal 125 
Sebagai contoh adalah proses perumusan kebijakan yang selama ini belum dapat dikatakan telah memfasilitasi peran serta warga masyarakat atau stakeholders terkait. c). Policy to foster innovation and its diffusion, yaitu kebijakan yang dimaksud adalah kebijakan yang khusus diciptakan untuk mendorong, mengembangkan, dan menyebarkan inovasi untuk berbagai sektor ${ }^{13}$

Terkait erat dengan kebijakan publik secara konseptual, maka peneliti mengemukakan definisi inovasi Administrasi Negara sebagai sebagai proses memikirkan dan mengimplementasikan kebijakan penyelenggaraan kepentingan publik yang original, penting, dan berdampak. ${ }^{14}$. Apabila dikaitkan dengan paradigma administrasi negara yaitu paradigma Old Public Administration (OPA), New Public Administration (NPA), New Public Manajement (NPM) dan New Public Services (NPS), maka paradigma New Public Services adalah yang paling tepat menerapkan prinsip-prinsip inovasi. Melalui NPS, publik dipandang secara utuh dan humanis, tidak direduksi sebagai pelanggan yang berciri ekonomistis-egoistis maupun sebagai pihak luar yang menjadi sasaran mekanis birokrasi $^{15}$. Selanjutnya disebutkan bahwa paradigma NPS juga menaruh perhatian yang besar terhadap inovasi dan bersifat integral serta komprehensif karena NPS merupakan pendekatan yang memberikan nilai tinggi pada kolaborasi antar pihak dan peningkatan kinerja setiap elemen organisasi. Hal ini berbeda dengan paradigma

13 Albury (2003) dalam Handbook Inovasi Administrasi Negara (2014:18).

${ }^{14}$ Handbook Inovasi Administrasi Negara, 2014, Pusat Inovasi Tata Pemerintahan Deputi Inovasi Administrasi Negara hal 17

${ }^{15}$ Ibid, hal 14 lainnya yang cenderung memandang inovasi secara terbatas dan parsial ${ }^{16}$.

Berikut akan penulis deskripsikan perbedaan paradgima administrasi negara dalam memandang inovasi.

\begin{tabular}{|c|c|c|c|c|}
\hline & OPA & NPA & NPM & NPS \\
\hline $\begin{array}{l}\text { Arti } \\
\text { Penting } \\
\text { Inovasi }\end{array}$ & $\begin{array}{l}\text { Kurang } \\
\text { penting }\end{array}$ & Penting & Penting & $\begin{array}{l}\text { Sangat } \\
\text { penting }\end{array}$ \\
\hline $\begin{array}{l}\text { Ranah } \\
\text { inovasi }\end{array}$ & $\begin{array}{l}\text { Integral } \\
\text { organisasi }\end{array}$ & $\begin{array}{l}\text { Praktik- } \\
\text { praktik } \\
\text { administrasi } \\
\text { publik yang } \\
\text { lebih adil dan } \\
\text { mampu } \\
\text { menyelesaik } \\
\text { an masalah } \\
\text { publik }\end{array}$ & $\begin{array}{l}\text { Hubungan } \\
\text { organisasi } \\
\text { publik- } \\
\text { pelanggan }\end{array}$ & $\begin{array}{l}\text { Holistik } \\
\text { dan integral }\end{array}$ \\
\hline $\begin{array}{l}\text { Tujuan } \\
\text { inovasi }\end{array}$ & $\begin{array}{l}\text { Menjalankan } \\
\text { sistem dan } \\
\text { aturan secara } \\
\text { efektif }\end{array}$ & $\begin{array}{l}\text { Menjalankan } \\
\text { sistem } \\
\text { administrasi } \\
\text { yang sadar } \\
\text { akan nilai } \\
\text { dan norma }\end{array}$ & $\begin{array}{l}\text { Meningkat } \\
\text { kan } \\
\text { produktivi } \\
\text { tas dan } \\
\text { efisiensi } \\
\text { kerja }\end{array}$ & $\begin{array}{l}\text { Memenuhi } \\
\text { kepentinga } \\
\mathrm{n} \text { publik }\end{array}$ \\
\hline
\end{tabular}

Sumber : Handbook Administrasi Negara - Pusat Inovasi Tata Pemerintahan Deputi Administrasi Negara, 2014

\section{Inovasi kebijakan publik konseptual} didefinisikan sebagai perubahan cara pandang atau masalah yang ada sehingga memunculkan solusi atau masalah. Ruang lingkup inovasi konseptual adalah kemunculan paradigma, ide, gagasan, pemikiran dan terobosan baru yang sebelumnya tak terbayangkan ${ }^{17}$.

Paradigma inovasi kebijakan publik telah menjadi diskursus dan praktek dalam birokrasi pemerintahan. Dalam konteks paradigma atau cara pandang tersebut, kebijakan publik dapat dipandang sebagai suatu proses yang berkesinambungan dan saling terkait yang dilakukan oleh pemerintah bersama stakeholder dalam mengatur, mengelola dan

\footnotetext{
${ }^{16}$ Ibid hal 14

${ }^{17}$ Direktori Administrasi Negara, 2014, Pusat Inovasi Layanan Publik Kedeputian Inovasi Administrasi Negara LAN - RI
} 
menyelesaikan urusan publik, masalah publik dan sumber daya yang ada untuk kepentingan bersama ${ }^{18}$. Salah satu daya saing inovasi dapat dilahirkan melalui pemikiran dan terobosan baru melalui strategi kebijakan. Kebijakan publik adalah fakta strategis daripada fakta politis ataupun fakta teknis. Sebagai sebuah strategi maka di dalam kebijakan publik sudah terangkum preferensi-preferensi politis dari para aktor yang teribat di dalam proses kebijakan, khususnya pada proses perumusan ${ }^{19}$

Inovasi telah menjadi bagian penting dari kebijakan publik. These questions about the nature of innovation and the dynamics that drive it are not new. Innovation has long been identified in the founda- tion texts of the social sciences as a major source of social development. ${ }^{20}$ Inovasi kebijakan publik dibuat untuk kepentingan publik dan bukan kepentingan privat maupun kelompok, kebijakan publik akan bermanfaat apabila dalam penerapannya berdasarkan kriteria-kriteria dan nilai-nilai normatif standar kebijakan. Dalam penelitiannya, Mark Considine, Jenny M. Lewis and Damon Alexander mengemukakan lima posisi normatif dalam inovasi

\section{The Five Normative Postions on Innovation}

\begin{tabular}{|l|l|}
\hline Institutional & $\begin{array}{l}\text { Innovation relies on } \\
\text { organizational factors }\end{array}$ \\
\hline Structural & $\begin{array}{l}\text { Innovation is about large } \\
\text { external change }\end{array}$ \\
\hline Sceptical & Uncertain if government has a \\
\hline
\end{tabular}

\footnotetext{
${ }^{18}$ Deddy Mulyadi, Loc. Cit

${ }^{19}$ Riant Nugroho, 2014, Public Policy, PT. Elex Media Komputindo Gramedia, Jakarta, hal 130

20 Mark Considine, Jenny M. Lewis and Damon Alexander, 2009, Networks, Innovation and Public Policy

Politicians, Bureaucrats and the Pathways to Change inside Government, Palgrave Macmillan, hal 3
}

\begin{tabular}{|l|l|}
\hline & role in innovation \\
\hline Incremental & $\begin{array}{l}\text { Innovation is about small, } \\
\text { planned improvements }\end{array}$ \\
\hline Adaptive & $\begin{array}{l}\text { Innovation means adapting } \\
\text { things from elsewhere }\end{array}$ \\
\hline
\end{tabular}

Sumber : Mark Considine, Jenny M. Lewis and Damon Alexander, 2009

Kriteria penentuan dalam inovasi

konseptual adalah sebagai berikut ${ }^{21}$ :

1. Inovasi ini lahir dari perubahan cara pandang atas suatu masalah yang kemudian diwujudkan dalam kebijakan;

2. Penilaian atas kesuksesan ini dapat dilihat dengan membandingkannya dengan kebijakan sebelumnya yang dilandasi oleh cara pandang lama. Apabila hasil atau kinerja kebijakan baru lebih baik, maka inovasi kebijakan konseptual dapat dikatakan berhasil;

3. Biasanya, perubahan cara pandang ini dilakukan dengan melihat suatu isu dengan perspektif yang lebih positif atau dengan melakukan paradgima.

Dalam perspektif konseptual, inovasi kebijakan akan terkait dengan perubahan cara pandang terhadap permasalahan sedang terjadi. Kemampuan melihat permasalah dengan sudut pandang yang mutlti paradigma akan melahirkan pemikiran yang lebih konseptual. Kemudian membandingkan kebijakan lama dan kebijakan baru dapat dilihat sebagai ukuran keberhasilan sebuah inovasi kebijakan, apabila kinerja kebijakan baru yang telah dilakukan inovasi berhasil, maka dapat disimpulkan kebijakan tersebut berhasil. Selanjutnya inovasi kebijakan dapat dianalisis dengan melihat isu yang sedang terjadi melalui perspektif positif. Perubahan

\footnotetext{
${ }^{21}$ Handbook Inovasi Administrasi Negara, op.cit hal 26
} 
perspektif positif dengen pembaruan paradigma tersebut dapat terjadi apabila semua stakeholder yang terlibat dalam inovasi kebijakan mempunyai paradigma yang mengutamakan sinergitas.

\section{C.3. Inovasi Kebijakan Publik dalam perspektif empiris}

Terdapat beberapa jenis inovasi kebijakan publik $^{22}$, yaitu jenis inovasi proses yang terdiri dari standar operasional prosedur, tata laksana, sistem dan prosedur. Kemudian jenis inovasi metode yang terdiri dari strategi, cara dan teknik baru. Dan jenis inovasi produk yang terdiri dari fisik (barang) maupun non fisik atau imaterial (jasa). Pada tataran empiris, manfaat inovasi dapat diidentifikasikan dalam beberapa manifestasi, antara lain: percepatan proses atau prosedur kerja, peningkatan efektivitas dan efisiensi dalam penggunaan sumber-sumber daya, pengintegrasian beberapa jenis layanan menjadi terpadu, perluasan pilihan publik (public choice) terhadap barang-barang publik (public goods), penguatan public engagement dalam pengambilan keputusan atau kebijakan publik, pengurangan beban masyarakat atas layanan pemerintah, serta model- model manfaat lain yang terus berkembang sesuai dinamika kebutuhan organisasi publik dan kalangan stakeholder-nya ${ }^{23}$

Secara empiris, inovasi kebijakan berdasarkan proses lebih menekankan pada

\footnotetext{
${ }^{22}$ Direktori Administrasi Inovasi Administrasi Negara, 2014, Pusat Inovasi Pelayanan Publik Kedeputian Inovasi Administrasi Negara, Lembaga Administrasi Negara, Cet 1 Jakarta PIPP-LAN

23 Tri Widodo Wahyu Utomo, 2016, Innovation Discussion Paper, Inovasi sebagai keniscayaan baru dalam ilmu dan praktek Administrasi Publik di Indonesia, Deputi Administrasi Negara, Lembaga Administrasi Negara
}

kualitas proses kerja baik eksternal maupun internal agar lebih sederhana dan efisien. Berikut adalah contoh-contoh dari penerapan produk inovasi kebijakan.

Produk Inovasi : Perubahan Pelayanan
Penertiban Paspor, Jenis Inovasi : Proses,
Unit Pelaksana : Kantor Imigrasi Kelas 1
khusus Jakarta Selatan, Penggagas :
Direktorat Jenderal Imigrasi.
Sistem Pelayanan Penerbitan Paspor Terpadu
(SPPT) / Sistem One Stop Service $\quad$ (OSS)
merupakan terobosan Direktorat Jendral
Imigrasi Kementerian Hukum dan HAM
berupa penyederhanaan atas prosedur birokrasi
yang panjang yang sebelumnya harus mengantri
4 kali menjadi mengantri 1 kali dalam
mendapatkan pelayanan paspor. Terobosan ini
dinilai sangat sesuai dengan moto Dirjen
Imigrasi yakni " menuju pelayanan yang lebih
aman, mudah, transparan, serta memberikan
kepastian dengan pemanfaatan teknologi
informasi". Harapannya adalah r untuk
meningkatkan kepuasan masyarakat ketika
mengajukan permohonan penerbitan paspor di
setiap kantor Imigrasi. Teroboson ini
dilatarbelakangi oleh permasalahan yang
dihadapi oleh Dirjen Imigrasi

Sumber : Direktorat Inovasi Administrasi Negara, Pusat Inovasi Pelayanan Publik, 2014

Fakta empiris inovasi metode lebih ditujukan dalam menerapkan sebuah cara, strategi dan teknik baru untuk mencapai hasil yang lebih baik. 


Produk Inovasi : Pelayanan Pertanahan
Jemput Bola, Jenis Inovasi : Metode, Unit
Pelaksana : Kantor Pertanahan, Penggagas :
Badan Pertanahan Nasional RI
Layanan Jemput Bola "LARASITA" merupakan
layanan pertanahan bergerak (mobile land
service) yang bersifat pro aktif dengan
"hadirnya" petugas BPN RI ke tengah-tengah
masyarakat. Secara praktis, kegiatan yang
dilaksanakan oleh LARASITA sudah
menegaskan perbedaannya dengan loket Kantor
Pertanahan. Kemampuannya menyentuh dimensi
sosial dari pengelolaan pertanahan pada
prosesnya akan memberikan kesempatan lebih
besar untuk melakukan tugas-tugas
pengelolaan pertanahan, dimana seringkali
tugas-tugas tersebut tidak mampu dijangkau oleh
interface Loket Kantor Pertanahan karena
formalitasnya. Dengan kemampuannya itu pula,
LARASITA diharapkan mampu menjembatani
BPN RI dengan masyarakat pemangku
kepentingan pertanahan, yaitu masyarakat yang
mempergunakan tanah sebagai basis
sumberdaya untuk penghidupannya

Sumber : Direktorat Inovasi Administrasi Negara, Pusat Inovasi Pelayanan Publik, 2014

\begin{tabular}{|lcrr|}
\hline Prodok Inovasi & Metode & \multicolumn{2}{c|}{ Partisipasi } \\
masyarakat & dalam & \multicolumn{2}{c}{ perencanaan } \\
Pembangunan & Bidang & Kesehatan, Jenis \\
Inovasi : Metode, Unit Pelaksana : Kabupaten \\
Buton Utara & & & \\
Kampo Waraka merupakan & upaya & yang \\
dikembangkan & pemerintah & Kabupaten & Buton \\
Utara untuk mendorong partisipasi masyarakat \\
dalam perencanaan & pembangunan & bidang \\
\hline
\end{tabular}

kesehatan sekaligus mendukung pemerintah daerah menyusun dokumen perencanaan dan penganggaran daerah berbasis web mutakhir. Upaya ini diterapkan akibat adanya banyak temuan data tentang gizi buruk, kekurangan gizi, lumpuh layu, kaki gajah dan kematian ibu bersalin. Selain itu, kurangnya fasilitas kesehatan yang terdapat di daerah tersebut karena pembangunan fasilitas kesehatan tersebut belum selesai. Pelaksanaan Kampo Waraka dilaksanakan melalui penerapan upaya antara lain 1) mengembangkan kemitraan bidan, dukun dan kader posyandu 2) mengembangkan insentif bagi ibu hamil resiko tinggi dari keluarga miskin 3) mendorong akselerasi pembangunan sarana dan prasarana kesehatan.

Sumber : Direktorat Inovasi Administrasi Negara, Pusat Inovasi Pelayanan Publik, 2014

\section{Produk Inovasi : Distribusi Guru PNS Proporsional, Jenis Inovasi : Metode, Unit Pelaksana : Dinas Pendidikan Kabupaten} Luwu Utara

Distribusi Guru PNS Proporsional DGP merupakan pemindahan guru PNS antar satuan pendidikan, antar jenjang, antar jenis pendidikan, antar kecamatan, antar kabupaten, dan antar provinsi dalam rangka peningkatan mutu pendidikan. Selain itu juga untuk menata ulang agar rasio, kualifikasi akademik, distribusi, dan komposisi guru PNS sesuai dengan kebutuhan riil masing-masing satuan pendidikan. Tujuan DGP antara lain : 1) tuntutan masyarakat untuk mendapatkan pelayanan Pendidikan yang berkualitas, akuntabel dan transparan, 2) peningkatan SPM Pendidikan dan 
perbaikan layanan melalui PBM berkualitas secara kontinu dan berkelanjutan, dan 3) mendorong partisipasi publik melalui FMS dan Warung Demokrasi dari tahap perencanaan hingga monev. Program DGP ini dilatarbelakangi ada kesenjangan besar dalam distribusi. kelas dan guru mata pelajaran. Data menunjukkan bahwa hanya $47 \%$ dari 259 sekolah dasar di Kabupaten Luwu Utara yang memiliki cukup guru kelas PNS. Melihat kenyataan seperti itu dibutuhkan suatu upaya untuk membantu mengurangi kesenjangan pendidikan antara desa dan kota dan akan meningkatkan kualitas pendidikan bagi anak anak di daerah terpencil yaitu dengan Distribusi Guru PNS Proporsional (GDP). Strategi pelaksanaan DGP, antara lain : penguatan organisasi masyarakat sipil, pembentukan dan penguatan Forum Multi Stakeholder (FMS), Pembentukan tim teknis di lingkungan Pemda, advokasi kebijakan oleh tim teknis dan pemantauan dan evaluasi pelaksanaan kebijakan oleh FMS.

Sumber : Direktorat Inovasi Administrasi Negara, Pusat Inovasi Pelayanan Publik, 2014

Inovasi produk ditujukan untuk penciptaan atau modifikasi barang atau jasa untuk meningkatkan kualitas, citra, fungsi dan sebagainya dari barang atau jasa tersebut.

\begin{tabular}{l} 
Produk Inovasi : Pelayanan Pembuatan SIM, \\
Jenis Inovasi : Produk, Unit Pelaksana : \\
Satuan Pelaksana Administrasi (Satpas) SIM \\
Polda Metro Jaya. \\
Mendekatkan Pelayanan Pembuatan SIM pada \\
Masyarakat merupakan terobosan pelayanan \\
\hline
\end{tabular}

yang dilakukan oleh Satpas SIM untuk membuat pelayanan semakin baik dan mendekatkan pelayanan SIM pada Masyarakat. Terobosan ini dilatar belakangi oleh waktu pembuatan SIM yang relatif lama, pemusatan pelayanan, juga terjadinya pratek percaloan pembuatan SIM. Inovasi ini dilakukan untuk memberikan kemudahan masyarakat dalam mengakses lokasi dan menurunkan waktu proses pembuatan SIM, serta menghilangkan praktek percaloan pembuatan SIM. Strategi yang dilakukan adalah dengan membuka pelayanan pembuatan SIM di lima wilayah DKI Jakarta, menyediakan fasilitas SIM keliling di lima wilayah DKI Jakarta, Gerai SIM, standarisasi waktu pelayanan pembuatan SIM, SIM komunitas, banking system, online system, komputerisasi ujian SIM, penggunaan access card, program bimbingan, dan aplikasi komputer database. Selain strategi tersebut Satpas SIM membuat lingkungan kantor senyaman mungkin seperti menyediakan ruang pengaduan, ruang bermain, ruang menyusui, ruang perpustakaan, fasilitas ibadah, tempat parkir kendaraan yang luas

Sumber : Direktorat Inovasi Administrasi Negara, Pusat Inovasi Pelayanan Publik, 2014

Produk Inovasi : Modernisasi KIA dan sistem
relasi Catatan Kelahiran, Jenis Inovasi :
produk, Unit Pelaksana : Disdukcapil bagian
bidang data dan statistik Surakarta
Kartu Insentif Anak atau KIA merupakan kartu
yang diberikan kepada anak-anak di Surakarta
yang berumur 0-18 tahun dengan bentuk seperti
KTP. Kartu ini sebagai bentuk solusi bagi
anak-anak untuk mendapatkan pelayanan publik


terbaik sesuai dengan yang dimandatkan oleh norma internasional (Konvensi Hak Anak PBB) dan Nasional (UU No.23 Tahun 2002 tentang Perlindungan Anak). Selama ini hak anak sebagaimana diamanatkan konvensi PBB dan UU No. 23 Tahun 2002 belum dilaksanakan sesuai dengan yang diharapkan Tujuan KIA adalah 1) memberikan fasilitas tertentu pada berbagai bidang sesuai kebutuhan anak, 2) untuk meningkatkan kesadaran orang tua dalam membuatkan akta kelahiran bagi anaknya, 3) untuk memberikan jaminan kesejahteraan, perlindungan dan fasilitas bagi anak. KIA memberikan kemudahan dan layanan bagi anak anak di kota Surakarta di bidang kesehatan, pendidikan, hiburan, olah raga, transportasi. Setiap anak yang memiliki KIA dapat memperoleh potongan harga pada sejumlah fasilitas yang telah bekerjasama dengan pemerintah kota Surakarta. Penerapan KIA diintegrasikan dengan pelayanan penerbitan akta kelahiran anak di Dinas Kependudukan dan Catatan Sipil (DKC) Kota Surakarta sebagai bagian dari penerapan kota layak anak.

Sumber : Direktorat Inovasi Administrasi Negara, Pusat Inovasi Pelayanan Publik, 2014

\section{Produk Inovasi : Sistem Pengolahan sampah plastik, jenis Inovasi : produk, Unit Pelaksana : Dinas Kebersihan dan Pertamanan Kabupaten Badung.}

Gerakan Berkelanjutan Anti Sampah Plastik (Gelatik) merupakan program unggulan mengurangi sampah plastik, juga mengubahnya menjadi energi terbarukan. Adapun tujuan pembentukan Program Gelatik tersebut bertujuan untuk menanggulangi sampah plastik dan membuatnya menghasilkan manfaatmanfaat ekonomis melalui pelibatan partisipasi masyarakat. Program Gelatik ini dilaterbelakangi oleh pengelolaan sampah plastik selama ini belum dilakukan secara optimal dan belum dapat menghasilkan produk-produk baru yang memilki nilai ekonomis tinggi Hingga saat ini program Gelatik telah menghasilkan sebuah reaktor pirolisis yang mampu mengolah sampah plastik menjadi sumber energi alternatif terbarukan, dimana manfaat gelatik power projek tahap I telah menghasilkan BBM, selain itu sampah plastik juga didaur ulang menjadi tas. "Guna mendukung program ini, tahun 2014 Pemkab Badung menggarkan dana sebesar Rp. 5,4 M untuk pembangunan 16 TPST. Agar program Gelatik mampu mengoptimalkan penanganan sampah plastik, maka Pemkab Badung melakukan strategi dengan melibatkan partisipasi masyarakat mulai dari sekolahsekolah, pasar tradisional, kelompok masyarakat maupun PKK. Beberapa komponen pendukung gelatik terdiri dari 118 sekolah, 132 unit pasar, kelompok masyarakat 24 unit, 6 kelompok PKK serta dukungan TPST (tempat pengolahan sampah terpadu) 3R (Reduce, Reuse, Reecycle).

Sumber : Direktorat Inovasi Administrasi Negara, Pusat Inovasi Pelayanan Publik, 2014

Inovasi kebijakan berbasis teknologi ditujukan untuk penciptaan atau penggunaan dari teknologi baru yang lebh efektif dan mampu memecahkan masalah. 
Produk Inovasi : Pengelolaan layanan online data kepegawaian berbasis WEB, Jenis Inovasi : Teknologi, Unit Pelaksana : Biro Kepegawaian dan Organisasi BPKP

SISPEDAP merupakan sebuah sistem pengelolaan data pegawai berbasis web (online) sehingga dapat terhubung langsung dengan pegawai dan unit kerja di seluruh Indonesia di manapun dan kapanpun sepanjang terhubung dengan internet. Permasalahan dalam pengelolaan data pegawai dengan jumlah pegawai yang cukup besar dan tersebar di seluruh wilayah Indonesia memunculkan dorongan untuk menciptakan sistem pengelolaan kepegawaian. Sistem ini tidak serta merta dapat diterima langsung oleh seluruh instansi pemerintah, mengingat hampir seluruh instansi pemerintah menciptakan sistem kepegawaiannya sendiri. Pegawai dan unit kerja dapat mengakses dan memutakhirkan data pegawai secara langsung (real time) dan setiap saat

Sumber : Direktorat Inovasi Administrasi Negara, Pusat Inovasi Pelayanan Publik, 2014

Inovasi Kebijakan berbasis struktur organisasi ditujukan untuk pengadopsian model organisasi baru yang menggantikan model lama dan tidak sesuai dengan perkembangan organisasi.

Produk Inovasi : Badan Pengelola Program Pemberdayaan Masyarakat, Jenis Inovasi : Struktur Organisasi, Unit Pelaksana : Badan Pengelolaan Keuangan Daerah Kota Kendari. BLUD kredit mikro Kota Kendari merupakan unit kerja dari Badan Pengelola Keuangan Daerah (BPKD) Kota Kendari yang mengelola program bantuan kredit mikro bagi masyarakat miskin yang kesulitan memperoleh dana bagi penguatan modal usahanya. Pada periode tahun 2007 sampai 2012 diindikasi bahwa masalah kemiskinan merupakan masalah mendesak untuk ditangani. Salah satu penyumbang angka kemiskinan terbesar adalah keadaan pedagang informal di Kendari yang sangat menyedihkan. Melihat kondisi tersebut, Walikota Kendari meluncurkan bantuan permodalan dalam bentuk kredit mikro kepada para pedagang keliling dan usaha kecil. Pemerintah Kota Kendari melihat perlunya upaya strategis melalui programprogram pemberdayaan masyarakat yang sebenarnya memiliki usaha jualan, diantaranya melalui Program Bantuan Kredit Mikro yang dikelola oleh Badan Layanan Umum Daerah (BLUD). BLUD Mikro Kota Kendari bertujuan untuk memberikan layanan peminjaman modal usaha. BLUD diarahkan untuk mengatasi kemiskinan struktural dengan memotong mata rantai rentenir serta menyediakan modal usaha sebagai bagian dari pemenuhan hak asasi masyarakat. Secara makro konsep BLUD mengadopsi Grameen Bank yang dikembangkan Muhammad Yunus. Teknis Pengelolaan Layanan Umum Daerah berpedoman pada Peraturan Menteri Dalam NegeriNo. 61 Tahun 2007 tentang Petunjuk Teknis Penyusunan dan Penetapan Standar Pelayanan Minimal. Dalam peraturan tersebut, BLUD diberikan keleluasaan untuk mengelola seluruh pendapatannya pada pasal 62 dan dibuatkan rekening khusus. BLUD Harum Kendari sendiri dalam pengelolaan keuangan, termasuk bagi hasil dan pendapatan lainnya memiliki rekening di Bank Pembangunan Daerah Kota Kendari atas nama 
Kantor Badan Layanan Umum Daerah.

Sumber : Direktorat Inovasi Administrasi Negara, Pusat Inovasi Pelayanan Publik, 2014

Secara empiris, inovasi kebijakan berdasarkan proses lebih menekankan pada kualitas proses kerja baik eksternal maupun internal agar lebih sederhana dan efisien. Beberapa contoh produk inovasi seperti perubahan pelayanan penertiban paspor yang digagas oleh Direktorat Jendral Imigrasi melalui Sistem Pelayanan Penerbitan Paspor Terpadu (SPPT) / Sistem One Stop Service (OSS) merupakan terobosan Direktorat Jendral Imigrasi Kementerian Hukum dan HAM berupa penyederhanaan atas prosedur birokrasi yang panjang yang sebelumnya harus mengantri 4 kali menjadi mengantri 1 (satu) kali dalam mendapatkan pelayanan paspor, contoh lainnya adalah produk inovasi pelayanan pertanahan jemput bola yang bertujuan lebih mendekatkan kepada masyarakat, pendekatan tersebut diharapkan menyentuh dimensi sosial dari pengelolaan pertanahan pada prosesnya akan memberikan kesempatan lebih besar untuk melakukan tugas-tugas pengelolaan pertanahan, dimana seringkali tugas-tugas tersebut tidak mampu dijangkau oleh interface loket kantor pertanahan karena formalitasnya.

Dalam menerapkan sebuah inovasi yang bersifat empiris, penekanan pada inovasi metode, strategi dan teknik menjadi sesuatu yang penting untuk mencapai hasil yang lebih baik. Begitu pula dengan penerapan inovasi produk yang ditujukan untuk penciptaan atau modifikasi barang atau jasa untuk meningkatkan kualitas, citra, fungsi dan sebagainya dari barang atau jasa tersebut. Dalam hal ini perangkat infastruktur berbasis teknologi diperlukan agar pelayanan yang dilakukan lebih efektif dan efisien serta mampu memecahkan masalah selain inovasi berbasis struktur organisasi yang bertujuan mengadopsi model organisasi yang fleksibel dan mampu mengadaptasi perkembangan organisasi.

\section{Penutup}

Inovasi dan kebijakan publik ibarat dua sisi dari keping mata uang yang sama. Inovasi berkontribusi dalam memberikan pengetahuanpengetahuan baru dan bermanfaat bagi kebijakan publik sedangkan kebijakan publik memberikan suplemen teori, pedoman dan metodologi yang dapat memperkuat inovasi kebijakan publik. Upaya-upaya inovasi kebijakan publik yang berdimensi kebaruan dan kebermanfaatan sehingga diharapkan dapat memberikan dampak pada upaya yang lebih kongkrit dan membangun partisipasi masyarakat secara berkesinambungan. Inovasi diterapkan bukan hanya pada tahap evaluasi kebijakan publik akan tetapi diterapkan sejak awal perencanaan kebijakan publik, implementasi dan evaluasi kebijakan publik. Inovasi kebijakan publik muncul bukan karena faktor leadership atau karena faktor terjadinya krisis yang memaksa organisasi untuk ikut melakukan perubahan, inovasi harus muncul dari sebuah sistem dan efek public manajemen knowledge yang dikembangkan oleh organisasi.

Keberhasilan inovasi diukur dari sejauhmana kinerja kebijakan publik mampu menjadi best solution bagi masyarakat. Sinergitas antara tataran konseptual dan empiris merupakan garis kontinum dalam upaya merekonstruksi 
inovasi kebijakan publik yang berkelanjutan. Framework struktur, kultur, teknologi dan kepemimpinan ${ }^{24}$ dapat menjadi tawaran konsep yang menarik dan perlu dipertimbangkan dalam membangun komitmen dan kesadaran inovasi kebijakan publik. Di sisi lain proses, dinamika dan praktek inovasi harus bersifat adaptif dan replikatif, hal ini penting karena beragamnya permasalahan dan karakteristik organisasi dan masyarakat. Salam Inovasi.

\section{DAFTAR PUSTAKA}

Considine, Mark : Lewis Jenny $\mathrm{M}$ and Alexander, Damon, 2009, Networks, Innovation and Public Policy

Direktori Administrasi Negara, 2014, Pusat Inovasi Layanan Publik Kedeputian Inovasi Administrasi Negara LAN - RI

Dwijanto, Agus et. al, 2007, Kinerja Tata Pemerintahan di Indonesia, Yogyakarta: Pusat Studi Kependudukan dan Kebijakan Universitas Gajah Mada (PSKK UGM)- Kemitraan.

Handbook Inovasi Administrasi Negara, 2014, Pusat Inovasi Layanan Publik Kedeputian Inovasi Administrasi Negara LAN - RI

Heruanto, Agus, 2006, Pusat Studi Kependudukan dan Kebijakan Universitas Gadjah Mada, http://cpps.ugm.ac.id

Lydia Wijayanti, 2012, Jurnal Pembangunan Wilayah dan Kota, Implementasi Kebijakan Pembangunan berkelanjutan di Kota Surakarta : Relokasi PKL di Taman Monumen Banjarsari ke pasar Klitikan Notoharjo

\footnotetext{
${ }^{24}$ Dasgupta dan Gupta, 2009 dalam Antonius Galih Prasetyo,2016 Innovation Discussion Paper, Deputi Inovasi Administrasi Negara, LAN-RI hal 6
}

Mariana, Dede, 2010, Otonomi Daerah dan Inovasi Kebijakan Publik, Jurnal Governance Vol. 1 No.1

Mulyadi, Deddy, 2015, Studi Kebijakan Publik dan Pelayanan Publik, Bandung, Alfabeta

Noor, Irwan, 2016, Jurnal Ilmiah Administrasi Publik Universitas Brawijaya Malang, Determinasi Pelayanan Publik Pemerintahan Daerah : Paradoks di Era Desentralisasi

Nugroho, Riant 2014, Public Policy, Teori, Manajemen, Dinamika, Analisis, Konvergensi dan Kimia Kebijakan (Ikapi Jakarta) 2014, Public Policy, PT. Elex Media Komputindo Gramedia, Jakarta

Pusat Invovasi Tata Pemerintahan Deputi Inovasi Administrasi Negara, 2014, Handbook Administrasi Negara, (Lembaga Administrasi Negara Pusat Intan - Dian - LAN)

Prasetyo, Antonius, Galih, 2016 Innovation Discussion Paper, Deputi Inovasi Administrasi Negara, LAN-RI

Widodo Tri Wahyu, 2016, Inovasi sebagai keniscayaan baru dalam Ilmu dan Praktek Administrasi Publik di Indonesia, Laskar Inovasi Deputi Inovasi Administrasi Negara 